\title{
New Data-driven Analysis and Policies to Regulate Commerce and Tourism: The Examples of Barcelona and Madrid
}

\author{
MAR SANTAMARIA-VARAS \\ $300.000 \mathrm{Km} / \mathrm{s}$
}

\begin{abstract}
The regulation of economic activity is a question of the utmost relevance in urban planning as urbanism meants to support coexistence of citizens necessities while preserving the health of the commercial economic fabric. In this context, the model of diversity embodied by the city of Barcelona (paradigm of other European cities where commercial and leisure activities play a fundamental role in constructing the social, civic and economic values) is under discussion from the urban and political perspective. The saturation of public access activities, food retailers and tourist services -consequence of previous boosting liberal policies- is affecting the habitability and the quality of life of the residents. Using the new land-use plan of Ciutat Vella (Barcelona, Spain, 2018) as a case study, we intend to frame the regulation of public access and commercial activities in an international context, explain how this particular type of plan works and discuss the circumstances of its implementation.
\end{abstract}

\section{INTRODUCTION}

A new land-use plan has been developed for the Ciutat Vella district in Barcelona (Spain) as a tool for regulating public access activities, food retailers, tourist services and other activities. This planning at the local level is meant to support coexistence with the neighbourhood's residents while preserving the health of the commercial economic fabric. It is the latest evolution of a planning tool that first emerged in 1992 during the initial 'explosion' of the socalled Olympic city, and which is now being reworked (at a time of intense debate about that economic model's effects on the city) in a context that is very different in many respects. The success of 'the new politics' candidature in 2015 represents a paradigm change in recent boosterist policy (Russo and Scarnato, 2017).

If previous conservative parties have helped to build the 'Barcelona Model' throughout developing large scale urban transformation and promoting the city as a tourist destination, this novel political movement seeks to reverse the consequent negative social impacts of both past local policies and the liberalization of the common economic market (European Directive of Services) by reclaiming the right to the city. Throughout this article, we intend to frame the plan in an international context with regard to the regulation of commercial activities, while explaining how it works and discussing the circumstances of its implementation.

\author{
PABLO MARTINEZ-DIEZ \\ $300.000 \mathrm{Km} / \mathrm{s}$
}

FROM POLICY PROMOTING ECONOMIC ACTIVITIES TO SATURATION AND THE LOSS OF LOCAL BUSINESSES

The image of a housing block where the ground floor is occupied by a café or a food retail establishment is characteristic of Barcelona and many other cities around the world. Indeed, commercial and leisure activities play a fundamental role in shaping the urban image and in constructing the social, civic and economic values that are generated at street level.

Businesses not only provide residents and visitors with goods and services, while providing jobs for a significant portion of the working population, they also end up becoming a driving force for development (generating benefits at an individual and collective level) and they create a feeling of belonging among residents in many urban areas (Ozoduru and Guldmann, 2013).

Scientific literature has contributed to demonstrating the value of the diversity of urban uses in European cities, specifically Mediterranean cities, highlighting concepts such as safety or the walkability associated with a commercial model centred on local businesses. In her book The Death and Life of Great American Cities, Jane Jacobs already asserted that, in the context of 1960s America, a city's diversity was rooted in a mixture of activities, smaller lot sizes to promote interaction between pedestrians, the coexistence of buildings dating from different time periods, and the need for building density as well as population density.

Along the same lines, Jan Gehl (2006) in his Close Encounters with Buildings and Manuel de Solà-Morales (2010) have advocated for the role of buildings' ground floors as a meeting place between architecture and the city, where residents experience buildings in their physical aspect, touching and being touched. According to these authors, the urban quality of architecture is expressed in façades, display windows, the thresholds of houses, restaurant terraces, corner shops, etc.

In that sense, the residential urban fabric that incorporates mixed uses on the ground floor not only generates a healthy economic activity for the city, it also provides services for residents, it expands the boundaries of public space, it increases safety when activities take place throughout the night, it has a positive impact on travel reduction by providing nearby access to basic necessities and, moreover, it ultimately becomes part of the city's identity. 


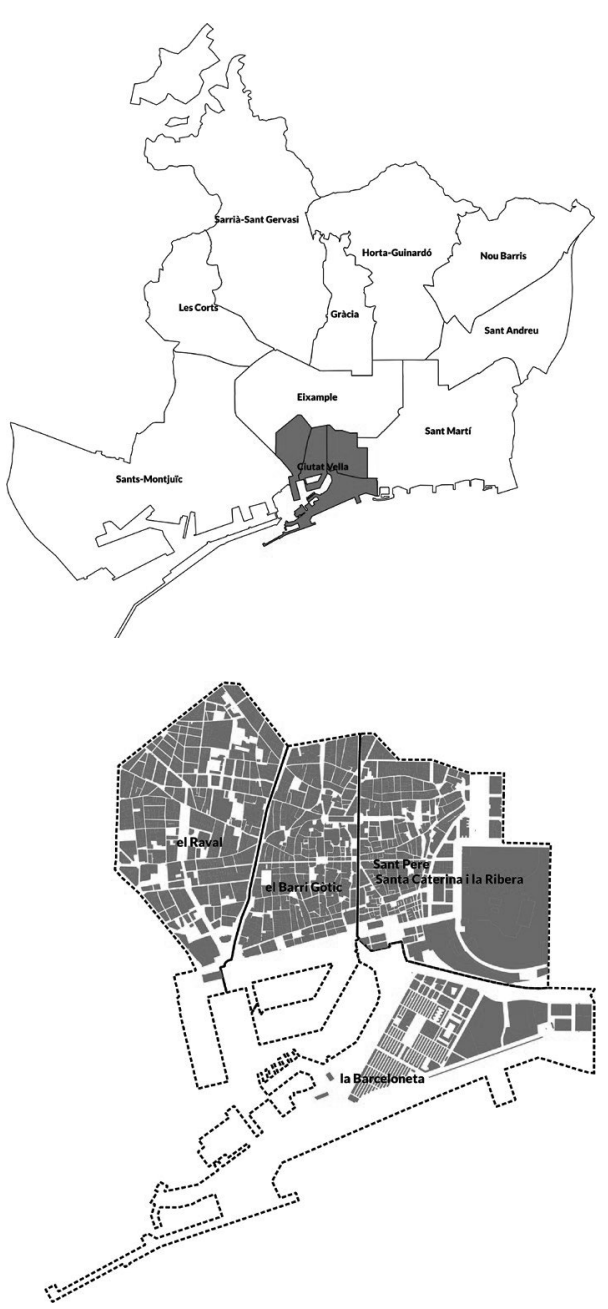

Figure 1. Ciutat Vella in the context of Barcelona (left) and district territorial divisions (right).

Many cities have inherited these archetypes and have been designed with them in mind, especially in the case historic city centres, even in cultural contexts where the urban fabric did not possess the necessary compactness, accessibility and mixture.

For example, in the United States a series of policies were developed in the 1970s for inner-city neighbourhoods, intended to revive local businesses that had been affected by large shopping malls and big-box stores in outlying areas. As recalled by Ozoduru and Guldmann (2013) quoting Robertson (2007), and by De Magalhaes (2012), these policies include: the National Main Street program that combined historic preservation and economic development with the central aim of reducing the physical deterioration of commercial thoroughfares; the Business Improvement Districts (BIDs) involving private sector investments and collaboration with the ultimate goal of reversing the dramatic decline in the economic health and environmental quality of cities; and the Centralized Management Scheme, managed by a team organising social activities and programs to help rebuild community spirit increasing participation of various stakeholders.

In recent years, policies have also been developed in England to recover the vitality of urban centres. According to Guy (2007), whereas during the 1960s and 1970s public policy showed a certain resistance toward including new forms of business, the regulations gradually became more flexible, tending toward a market-led approach that allowed for the development of new commercial formats. As a result, in the 1990s the focus was once again turned toward town centres, underscoring the competition with suburban shopping centres.

The largest influence on the current shape of the commercial fabric came no doubt from the Town Centre First Policy (Department of Environment, 1996). The goal of the TCFP was to 'redirect development, not just in retailing but in all "key Town Centre uses," including leisure, office development and other uses, such as restaurants, to Town Centres' under the premise that locating businesses in central, well-communicated areas would reduce the need for travel. As has been demonstrated by a number of studies (see Chesire et al., 2015; Guy, 1998; Guy and Bennison, 2007; Wood et al., 2006), this highly targeted policy regarding the insertion of economic activities has had a moderately positive impact in terms of attracting new development to urban centres. It has also compelled certain activities to adapt, through new business formats, to the fine grain characteristics of the urban fabric in city centres (i.e., in the case of large grocery retailers and supermarkets).

More recently, we have seen other examples where cities have had to fight against the loss of businesses resulting from the economic crisis of the early 21st century. The city of Detroit is the most notable example. Facing significant problems rooted population decline, and with large tracts of vacant land and abandoned buildings as the result of changes to the city's production model (the population has fallen by $25 \%$ in the last 10 years and the number of empty houses has doubled), the question of uses is a key issue.

With $36 \%$ of commercial lots pending occupation, the lack of economic activity is resulting in serious problems in terms of habitability and safety and a decline in quality of life. The new planning strategy for the next 50 years (Detroit Future City, 2014) uses a regulatory model based on the degree of vacancy in the urban fabric. The diversity of the vacant fabric allows for the reintroduction of new economic activities, the incorporation of green areas and landscaping, as well as a balance with urban uses. The uses are ordered according to their densities and, in most cases, based on a comprehensive vision of the different functions necessary for city life. 

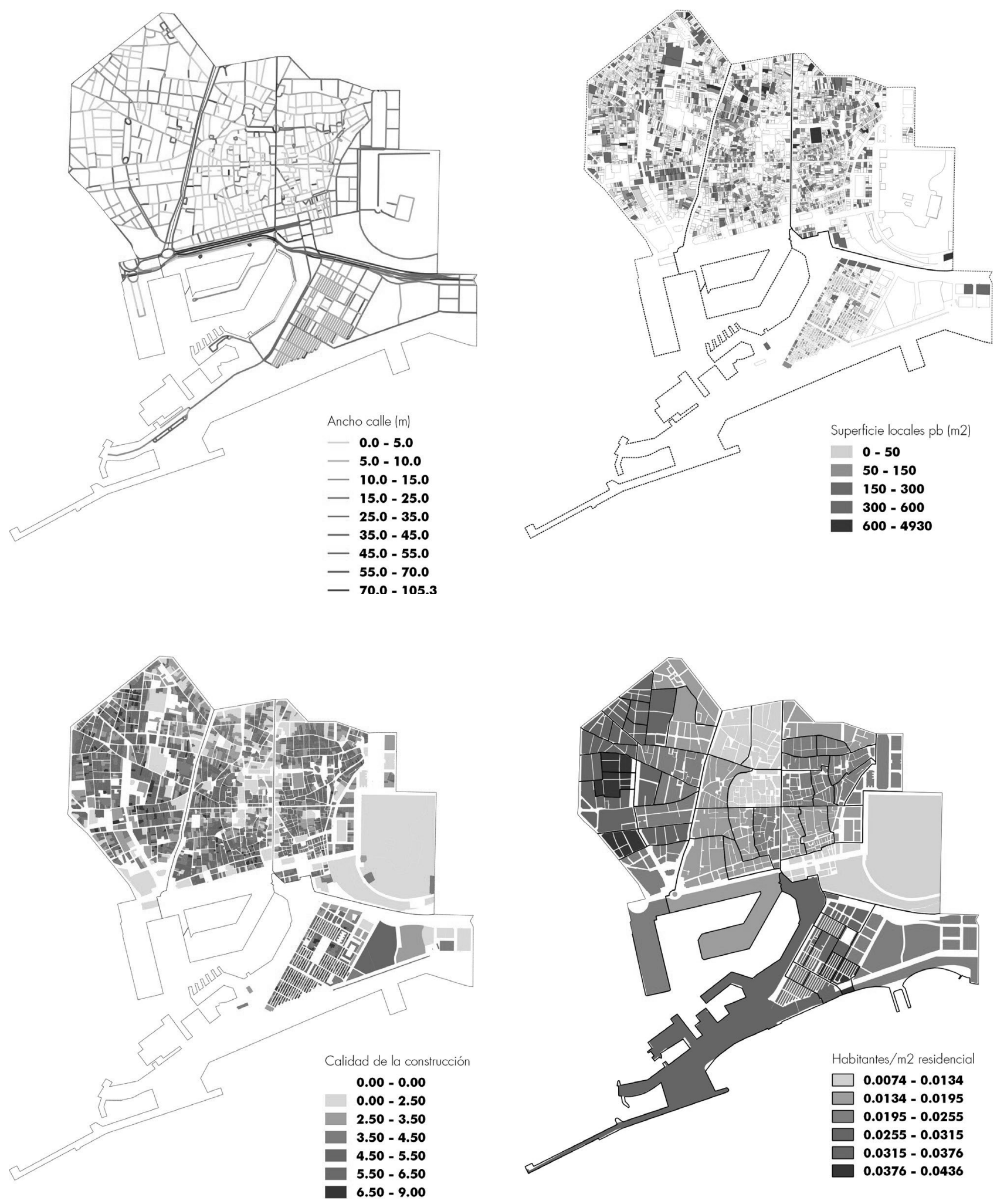

Figures 2, 3, 4, 5 Classification of streets according to street width (upper-left) and commercial premises according to surface (upper-right). Quality of construction (down-left) and distribution of population per residential surface (down-right). 
As we can infer from the analysis of the preceding examples, liberal policies that are linked to commerce have focused mainly on promoting economic activity as the driving force for transformation and the reactivation of urban centres, always with an eye to approximating the mixture and diversity embodied by the Mediterranean city - a model that, incidentally, is based on a very delicate balance between economic initiative and urban quality. What happens when that balanced is altered? The mixed-use model has been eroding in recent years as a result of the effects of market-led gentrification phenomena that are similar to what has occurred in the housing market. Urban uses are transforming rapidly, and this variation has a direct effect on the loss of services for residents, the substitution of symbolic establishments that may be social cornerstones, and the modification of the urban landscape in many cities.

These relationships between consumption and gentrification may be manifested physically in different ways, either through the proliferation of exclusive ('designer') establishments and stores selling expensive products (Massey, 2005; Lees et al., 2005) or places that aim to respond to consumption patterns of the middle classes (Pascual and Ribera, 2009) or creative classes (Florida, 2005), with the consequent disappearance of local businesses (small groceries, bakeries, stationery stores, etc.) or the introduction of establishments catering to tourists, which also have an impact on the expulsion of businesses oriented toward the local population (Cócola-Gant, 2015).

However, the substitution of local businesses that are a unique feature of a neighbourhood is not only an effect of private interest and market pressure. As posited in the work by Janochska et al. (2013) and Sequera (2015), the public authorities are also partially responsible for the commercial and productive changes that have been taking place in cities, especially in their urban centres. As those authors observe, the public administration has been implementing a series of boosting policies to retake the city for commerce, for the middle classes and, ultimately, for the market.

Yet, the right-wing public policies are not solely responsible for gentrification. Individual initiatives, tied to the emergence of the collaborative economy, also act as a powerful gentrifying agent, as we have seen with the Airbnb phenomenon (Stors and Kagermeier, 2017). Recent studies focusing on the impact of home-sharing on housing prices in the United States (Barron et al., 2017) have demonstrated aside from raising rents, long-term housing being transformed into tourist apartments generates an increase in the number of visitors to residential neighbourhoods with consumption habits that do not correspond to local businesses and who attract commercial activities tied to the tourism industry that have identical storefronts all around the world.
This eventually ends up creating a uniform image on cities' ground floors and leading to opposition from residents (Barcelona, Amsterdam, Madrid and Venice are clear examples of this phenomenon.)

\section{THE CASE OF BARCELONA AND ITS CENTRAL DISTRICT}

Ciutat Vella, Barcelona's central district, is a clear reflection of many of these issues. This district gathers all of the city's historical monumental fabrics: the ones that reveal the date of the city's founding along with its subsequent growth until the walls were torn down under the Cerdà

It is a compact fabric with an average floor area ratio of 4 $\mathrm{m} 2$ of built area/m2 of land and four storeys in the case of residential buildings, with very narrow streets $(31 \%$ are not wider than $10 \mathrm{~m}$, figure 2 ) and small plots $(60 \%$ of plots have less that $200 \mathrm{~m} 2$, figure 3). A large part of the city's most valuable historic heritage is concentrated there, dedicated to public services or emblematic buildings, while most of the lower-quality poorly preserved constructions are used for housing (figure 4).

Although it is not the largest district $(436.9 \mathrm{Ha})$, nor does it have the largest population (its 100,451 inhabitants make up $6.2 \%$ of the city's total population of $1,610,427$ inhabitants, figure 5), it is the densest (774 inhabitants/ residential $\mathrm{Ha}$ versus 622 inhabitants/residential $\mathrm{Ha}$ in the city as a whole) and one of the most severely affected by social vulnerability.

Historically, this fabric incorporated a lot of commercial activity (also workshops and warehouses) on the ground floors as a complement to housing; the latter use has been consolidated over the years as the most characteristic. Today, the commercial activity located on the ground floor is regulated by a maximum proportion established in the Metropolitan Master Plan (the current planning document that has regulated zoning in Barcelona and its metropolitan area since 1976) intended to provide a fabric of services for residents and production activities for the city.

Yet, this intended balance is broken when city centres end up clustering the services for the entire city, and for many of the nearby suburbs, or when they are outfitted with cultural infrastructures with a global reach that become a pole of attraction for visitors from all over the world. For example, Ciutat Vella concentrates all of the city's main administrative and cultural facilities; as a result, a large part of the surface area of the district is not dedicated to serving the residents. Similarly, the clients of the commercial activity in the district include its residents, but also a large floating population, which reaches nearly 30 million people in the case of Barcelona (versus a population of 1.6 million according to the census). Moreover, most of that population frequents the same areas of the city. 

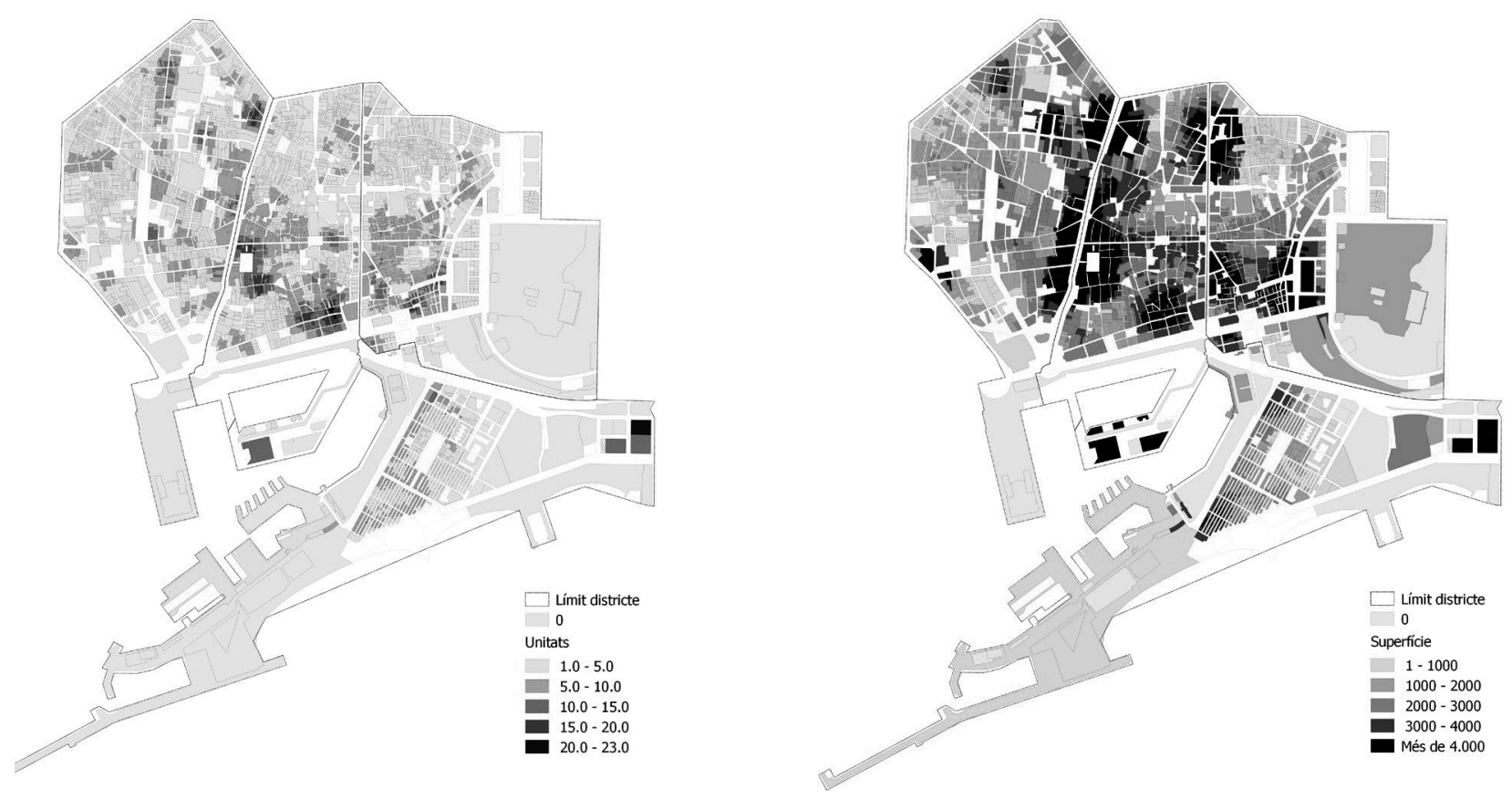

Figures 6, 7. Saturation of nocturnal leisure activities. Number of establishments (left) and surface of establishments (right). Darker spots represent highly saturated areas.

Again, this activity cannot maintain a proportion that is balanced with the services required by the residents.

On the other hand, much of the specialized business has gradually disappeared, due either to the new law on urban rents [Llei d'Arrendaments Urbans - LAU] or as an effect of online retail. Until its revision in 2013, the LAU made it possible for many commercial establishments with contracts prior to 1985 to maintain their original rents as listed in the initial contract. That allowed many low-profit commercial activities to continue operating, leading to a coexistence between modern businesses and other nearly obsolete activities such as shoe repair, stores selling professional fishing equipment, or tailors. Online sales have become a good alternative for specialized commerce, which has found a way to survive by gaining access to a larger audience. In some cases, it has even allowed economic activities with a very limited customer base to continue operating without the need for a physical store on the ground floor of the city.

Both of these phenomena - an increase in rents on historic contracts and the lack of a need for a physical headquarters have contributed to the disappearance of businesses (especially traumatic when they are emblematic establishments) that have gradually been replaced by leisure activities and restaurants all over the city of Barcelona, but especially in Ciutat Vella.

In fact, leisure activities and restaurants elicit the most demand among visitors to the district, who go there precisely because of the leisure offering. Currently, the absolute number and density of public access activities (2,161 establishments, equivalent to 5 activities/ $\mathrm{Ha}, 3,040$ if we include hotels) is much higher there than in other districts, which nevertheless also show an intense proliferation of this type of establishments.

This disproportionate number of activities translates into a clear impact in terms of cleanliness, noise, concentration of people in the public space or logistics demands, issues that can have a negative effect on residents' quality of life beyond the loss of services we referred to earlier.

Particularly the impact of noise resulting from leisure activities and restaurants - especially when they occur late at night - is also a problem that warrants growing concern in the district. According to the report by Barcelona's Public Health Agency (2016), Ciutat Vella is the district in the city with the largest percentage of people who are exposed to noise. The night noise levels recorded by different sound level meters located through the district are consistently higher than the maximums recommended by the WHO and the EU.

Finally, it is worth noting the proliferation of new commercial typologies not previously in existence in the district as a consequence of the strong presence of visitors and the appearance of $p 2 p$ vacation apartments.

Examples include rental agencies for personal transportation vehicles (bicycles, Segways, etc.), which create a serious impact on public roadways, or new establishments resulting 
from the transformation of the tourist accommodation sector and the segmentation of services that used to be centralized in hotels, such as tourist information, ticket sales or luggage storage.

This context, characterized by the transformation of commercial establishments and the oversaturation of certain uses, along with the effects of this situation on habitability and coexistence, is the framework for the development of the sixth land-use plan for the district, intended to reduce the conflict generated in the residential fabric by economic activity (consequence of previous boosting/ rightwing policies) and to maintain the balance between different urban uses.

\section{THE NEW LAND-USE PLAN FOR CIUTAT VELLA: CONTEXT AND URBAN PLANNING MECHANISMS}

As we saw in the previous sections with the analysis of international cases and the specific example of Barcelona, the regulation of economic activity is a question of the utmost relevance in urban planning with a strong political significance. In that sense, we need to find new planning formats and mechanisms that help achieve the delicate balance between economic initiative and urban quality. For example, the regulation of urban uses is often subject, on the one hand, to very generic categorizations (commercial, industrial, offices, residential) which are much more similar to zoning strategies than to urban design project, and, on the other hand, to individual private initiative, which is often governed by the opportunities and tendencies of the market to the detriment of urban quality.

As we are reminded by Piè and Vilanova (2016), in the mid1980 s the first "Plans d'usos" [land-use plans] were drawn up which, through the figure of the Special Plan, proposed a regulation and spatial planning that would be adaptable to the characteristics of a particular urban morphology. For the first time, the planning of uses was put in the foreground - something that had never happened traditionally, since the central question in urban planning had always been the forma urbis. It is also worth emphasizing that the typology of the Special Plan is necessary because the general planning in the municipal sphere (in the case of Barcelona, the Metropolitan Master Plan of 1976) regulates uses in a very generic way, responding to the type of urban fabric and the land's zoning classification.

Land classification is specific to every municipality, as is the computation of the different land uses allowed in each area of the city and the urban mixture that arises. In this context, the figure of the land-use plan serves to regulate the concession of licenses for public access activities and other activities, since it is an instrument that further develops the general planning and determines the location conditions for establishments in a partial area, normally a district.
In the particular case of Ciutat Vella, most of the urban fabric is classified as Nucli Antic, where residential uses are compatible with commercial, industrial and office uses, among others, with a limit on floor area that depends on location (on the ground floor or other floors). This lack of specificity generates a situation of competition between residences and other economic activities, where, for example, hotels and tourist apartments, offices, or businesses are uses that can have an impact on availability of residential land or an increase in its price.

The planning is revised periodically, taking into account, on the one hand, that the changes in uses on the ground floor can take place much faster than the physical transformation of the city itself and, on the other, that urban, social and economic conditions are variable and that adjustments must be made based on the specific conditions at a particular moment in time. In that sense, over the years land-use plans have incorporated new activities that need to be regulated, either due to the emergence of new establishment formats, in order to provide a response to issues of coexistence, or as an adaptation to new regulatory contexts. So, whereas in the first land-use plans (from 1992 to 2010) the focus of the planning was on restricting activities associated with restaurants, gambling and hotels - initially, in response to neighbourhood deterioration and problems involving drugs and prostitution, and later due to the proliferation of tourist apartments - new activities were later added, including food retail in all its variations (prepared food, tastings, take out).

The new land-use plan for 2018 has tended to simplify the range of activities regulated in the older plans, adapting to recent regulatory changes and grouping them according to a greater or lesser degree of nocturnal impact in response to the problems of coexistence detected during the diagnosis and participatory process. New activities related to tourism have also been included (car rental, ticket sales, travel agencies, luggage lockers) in line with other cities suffering from similar problems, like Amsterdam, which recently banned cheese stores in its central district.

Yet, one of the biggest changes that has taken place in the past 25 years, since the approval of the first land-use plan, was the entry into force of Directive 2006/123/CE of the European Parliament, which eliminated a large number of the restrictions imposed on accessing or exercising a service activity. This policy was one of the fundamental reasons for the partial annulment of the land-use plans of 2010 and 2013, which imposed conditions on the process of accessing and establishing economic activity that were not urbanistic in nature.

In that sense, the new 2018 land-use plan conforms to Article 9 of the Services Directive, which specifies that the latter does not applicable to the requirements derived from regulations relative to urban planning, which must be respected by suppliers in the exercise of their economic activity as well as by 
individuals in their private capacity. As such, the limitations foreseen in the plan are justified by pressing reasons rooted in the general interest - the protection of the urban milieu and the environment - and they should be deemed justified and commensurated in the pursuit of desired goals.

Finally, it is worth pointing out that the development of this new plan was also an opportunity to improve the accuracy of planning tools and review the zoning criteria in order to implement regulations keeping with the specificities of the planning conditions and the saturation of each plot and each building in the district. As such, a single regulation zone is established (Zona Única) along with three types of conditions that are intended to regulate the implementation of establishments based on: 1) the location relative to housing, protected facilities and uses, and other establishments or according to the vulnerability of the fabric; 2 ) the zonal location (where an activity is limited to certain routes) or 3 ) the specific conditions of the establishments themselves (maximum surface area, regulation of warehouse spaces).

Of all these conditions, the location relative to other establishments is especially relevant, since it translates into a maximum density of establishments within a particular radius. As its main new addition, the 2018 land-use plan introduces a density calculation in the tabulation of usable floor area for activities within two consecutive radii of 50 and 100 metres, where the impacts of the establishments of a similar category and the ones that have the largest nocturnal impact, respectively, are added together.

The application of these urbanistic parameters is intended to permit the introduction of activities in cases where the urban fabric can still support them, while restricting activities where their concentration is detrimental to maintaining a mixture. We must remember that the ultimate goal of this plan is to guarantee the habitability of the residential fabric of the district as one of its fundamental characteristics. That implies maintaining the residential volume, preventing its decrease as a result of displacement caused by the densification of activities and the loss of a characteristic mixture of uses, while ensuring the conditions of habitability by minimizing the damages to residents' quality of life and to their health caused by these activities.

The mixture of uses in the district of Ciutat Vella is currently in a delicate state of balance, which harmonizes the residential use and the services those residents need (facilities and retail services) with the productive economic activities and the cultural activities that provide services to the district, the city, the metropolitan region, and also to visitors from around the world who travel to the city. This mixture must be balanced and distributed to ensure that all its different elements can develop appropriately. That is why the land-use plan for the district of Ciutat Vella does not set out to define an economic model. Instead, it defends an urban and political model where the urban fabric must provide the maximum conditions of comfort and habitability to its residents, while also protecting the urban milieu.

\section{REFERENCES}

Barron, K., K. Edward, and D. Proserpio. "The Sharing Economy and Housing Affordability: Evidence from Airbnb." SSRN. Accessed October 5, 2017. https://ssrn. com/abstract $=3006832$.

Cheshire, P., C. Hilber, and I. Kaplani. "Land Use Regulation and Productivity-Land Matters: Evidence from a UK Supermarket Chain." Journal of Economic Geography 15, no. 1 (2015): 43-73.

Cócola-Gant, A. "Tourism and Commercial Gentrification." In RC21 International Conference - The Ideal City: Between Myth and Reality. Representations, Policies, Contradictions and Challenges for Tomorrow's Urban Life, Urbino, Italy (Augus 2015): 27-29.

De Magalhaes, C. "Business Improvement Districts and the Recession: Implications for Public Realm Governance and Management in England." Progress In Planning 77, no. 4 (2012): 146-177

Findlay, A. and L. Sparks. "Retail Planning Policy in the United Kingdom (UK)." Institute for Retail Studies. University of Stirling, Scotland, UK. 2013.

Florida, R. The Rise of the Creative Class: And How it's Transforming Work, Leisure, Community and Everyday Life. New York: Basic Books. 2002.

Gehl, J., L. Johansen, and S. Reigstad. "Close Encounters with Buildings." URBAN DESIGN International 11 (2006): 29-47.

Guy, C.M. "High Street Retailing in Off-Centre Retail Parks: A Review of the Effectiveness of Land Use Planning Policies." Town Planning Review 69 (1998): 291-313.

Guy, C.M. and D. Bennison. "Planning Guidance and Large Store Development in the UK: The Search for Flexibility." Environment and Planning 39 (2007): 945-964.

Jacobs, J. The Death and Life of Great American Cities. New York: Vintage. 1992.

Kagermeier, A. and N. Stors. "The Sharing Economy and its Role in Metropolitan Tourism." In Tourism and Gentrification in Contemporary Metropolises. GravariBarbas, M. and S. Guinard, eds. London: Routledge. 2017.

"The Land Use Element: The Image of the City." Detroit Future City official website. Accessed December 20, 2017. https://detroitfuturecity.com/wp-content/ uploads/2014/02/DFC LandUse_2ndEd.pdf.

Massey, J. "The Gentrification of Consumption: A View from Manchester." Sociological Research Online 10, no. 2 (2005). http://www.socresonline.org. uk/10/2/massey1.html.

Ozuduru, B. and J. Guldmann, "Retail Location and Urban Resilience: Towards a New Framework for Retail Policy." S.A.P.I.EN.S 6. no. 1 (2014). http://journals.openedition.org/sapiens/1620.

Piè, R. and J. Vilanova. "Instruments de planificació i gestió urbanística entorn del turisme." Report document on the Strategic Tourism Plana of Barelona, 2020.

Pascual, N. and R. Ribera. "Retail Gentrification in Ciutat Vella." In Whose Urban Renaissance? An International Comparison of Urban Regeneration Strategies. Porter, L. and K. Shaw, eds. London: Routledge. 2009.

Robertson, K.A. "Downtown Redevelopment Strategies in the United States: An End-of-the-Century Assessment." Journal of American Planning Association 61, no. 4 (2007): 429-437.

Russo, A.P. and A. Scarnato. "'Barcelona in Common': A New Urban Regime for the 21st-Century Tourist City?" Journal of Urban Affairs 40, no 4 (2018): 455-474. 10.1080/07352166.2017.1373023.

Smith, N. The New Urban Frontier: Gentrification and the Revanchist City. London: Routledge. 1996.

Solà-Morales, M. "La urbanitat de l'arquitectura: conferència inaugural del 20092010." Visions 8 (2010): 7-25. http://upcommons.upc.edu/handle/2099.2/1236.

Wood, S., M. Lowe, and N. Wrigley. "Life after PPG6: Recent Food Retailer Responses to Planning Regulation Tightening." International Review of Retail, Distribution, and Consumer Research 16 (2006): 23-41. 